\title{
THE RECENT FINDINGS OF THE NASAL MENINGITIS
}

\author{
By \\ Takeshi HIROSE AND Kazushige NIWA \\ From the Department of Oto-Rhino-Laryngology, Faculty of Medicine, \\ Shinshu University, Matsumoto (Director: Prof. T. Suzuki)
}

The authors report 3 cases of suppurative meningitis caused by comprehensive resection of upper jaw cancer and a statistical observation of the nasal supprative meningitis was attempted.

In reviewing 28 cases of this disease reported in the literatures since 1956 in Japan comparing with before, the following facts are established:

1) The death-rate;

(a) Before the introduction of antibiotics: $91.4 \%$

(b) After the introduction of antibiotics: $18.7 \%$

I stage $(1949 \sim 1952): 40 \%$

$$
\begin{aligned}
& \text { II stage }(1953 \sim 1955): 15 \% \\
& \text { III stage }(1956 \sim 1961): 10.7 \%
\end{aligned}
$$

(c) There is a significant difference in deathrate between spontaneous infection ( 33.3 $\%)$ and operative origin $(0 \%)$ in our III stage.

2) The facts show that the advancement of antibiotica has brought wonderful changes for the treatments and prognosis of nasal meningitis.

3) The new disease named "postoperative repeated nasal meningitis" has been described in 8 cases since 1956 and the authors have discussed the stati* stical observation of this disease.

\section{鼻 性鹃道膜炎最近の知見}

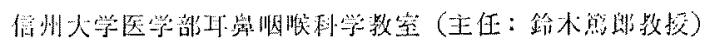

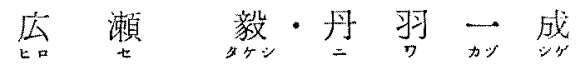

\section{I 緒 言}

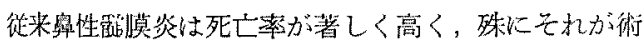
後性に発来した場合には術者のらける苦悦は言語に絶す

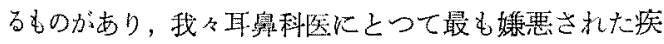
腎の1つであつた。しかしながら近年の抗生物犋の劃期

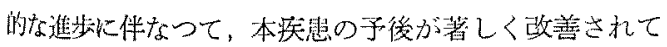
きていることは真に暿ばしいことである。

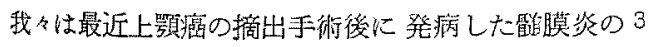
治教例を相次いで経験し，抗生物質の卓效に警歏したの

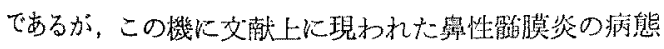

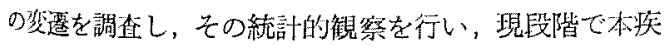

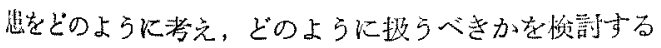
ことの有意䣡なことを考えて本篇をまとめてみたのであ

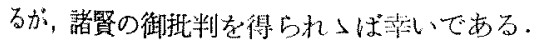

$$
\text { II 症例 }
$$

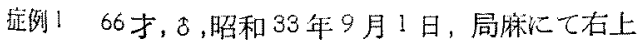

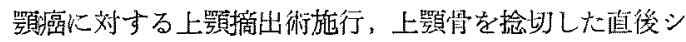
ヨック状態になつたので,眼蒚内容除去術は9月15日に

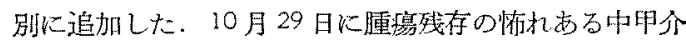

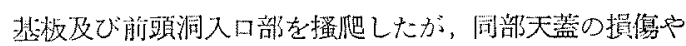

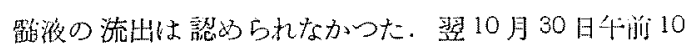
時頃，㖶吐を伴ら琶寒戦慄が起る。この㭙発熱はない。

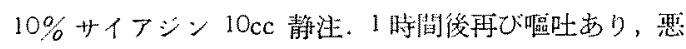
藇戦保持航し， $39.7^{\circ} \mathrm{C}$ に発熱，クロマイ $\mathrm{lg}, \mathrm{PC} 60$ 万

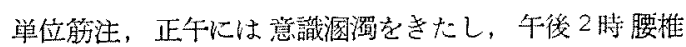

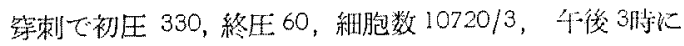
は搜衣模彇，項部强值が著明に現われ、、ロイコマイシ ン $600 \mathrm{mg}$ 及び $10 \%$ サイアジン $10 \mathrm{cc}$ 静注. 少後?狩 には腰椎穿刺で初压 $220,30 \mathrm{cc}$ 排除, 終压30, ところ

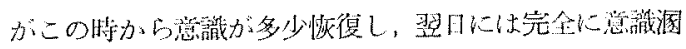

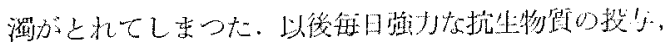

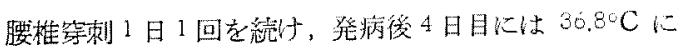


なり，䯠液絸胞数の又, 300～600 を数えたが，全身状態 は全く軽快した，以後ラジウム，レントゲン照射治療後 退院したが，癌再発のために死亡。

症例 2.67 寸，古，炤和 35 年 11 月 28 日，気管国開

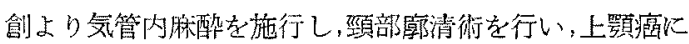

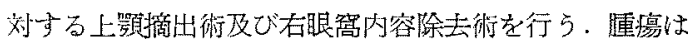

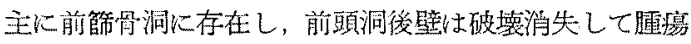

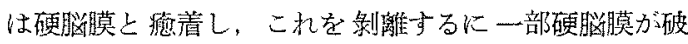

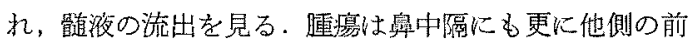
穊骨蜂巣にも浸潤して，この部の腫晹を除去するため両

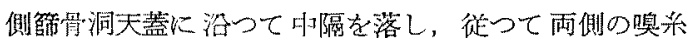
を殆ど 全部切断した，局所には静注用アクロマイシン $100 \mathrm{mg}$ 溶液に浸したがーゼを当て，術後は当日よりク ロマイ $\mathrm{lg}$ 筋注, ロイコマイシン $200 \mathrm{mg}$ 静注を連日行 つていたが，術後6日目に頭痛，墨心を伴な5 $38.5^{\circ} \mathrm{C}$ の発熱市り, 直ちに腰椎等刺学行い, 初圧 220 , 細胞数 $2000 / 3,10 \mathrm{cc}$ 排除後 PC 10 万箪位を䯚腔内注入，以

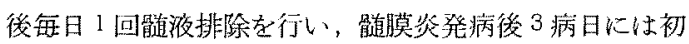

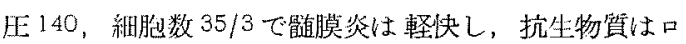
イコマイシン $800 \mathrm{mg}$ 内服のみにきりが，12月14日 上り放射線治療を開始し，以後全身状態には変化なく， 36 年 2 月 21 日退院したが，同年3月30日死亡.

抬例 3.59 才。古，昭和 36 年 8 月 28 日，気管切閉創

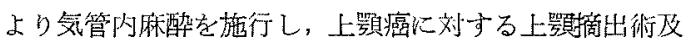
V“腿窝内容除去術を施行。術直後Co 60 tube $(4$ 本, $10 \mathrm{mC})$,

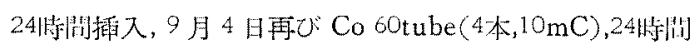

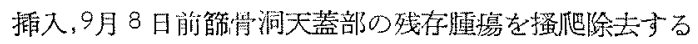
際，同部骨を破損し，䯣䧹多量飞流出する，同部には注射 用クロマイの溶液を浸したスポンゼルを当て, 術後直ち にアイロタイシン $250 \mathrm{mg}, 4$ 㬨间每化静注及び同量内服

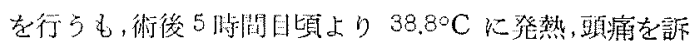

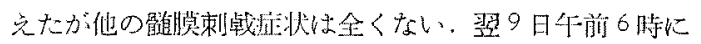

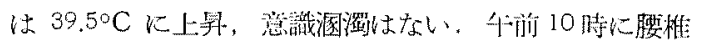
第溂, 初生 $230,15 \mathrm{cc}$ 排除, 終正 80 , 維胞数 $5200 / 3$,

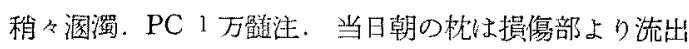
した䯣液によつてびつしより濡れていた。种前 11 時頃頭

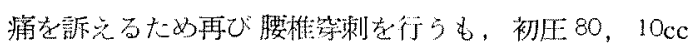

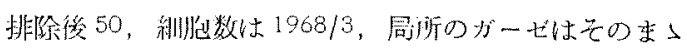
にして去の上から注射咸タロマイ $\mathrm{g}$ 老 $10 \mathrm{cc}$ に溶船し たもの約 $3 \mathrm{cc}$ 起注入，以後网様な抗生物質の投与に上

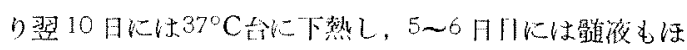

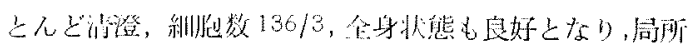
から陗液の流出もなくなつたので，以後はアイロソンの
内服のみにして発病後8〜9日目には微熱を残して全身 状㑷は全く軽快した１0月9日よりレントゲン迴転昭 射 $6000 \gamma$ 省行い，現在経過観察中である。

\section{III 文献上の統計的観察とその考察}

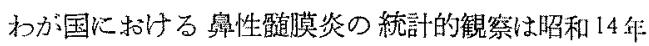
稻村氏が 40 例を集計報告したのが初めてざあり，以後 昭和 28 年寺山氏が稻村氏以降の 21 例を集計し，炤和 33 年小川氏は封山氏以降の昭和 31 年迄の 11 例を集計し, 同年本杉氏は小川氏とは別に 寺山氏以降の昭和 31 年迄 の22 例の集計を行つている.今回我々が集計したもの は小川氏，本杉氏以队降の症例て昭和 31 年から昭和 36 年 迄の文献及び証例報告の28例である．統計的観察の方 法は稲村氏及び寺山氏に準じ，これに若干の修正を加え て試みてみた。

性別では罗性 10 例，女性 10 例，不明 8 例，平均年令 は男性 24 才，女性 21 才で，これらはいずれもこれまで の統計と同し範图に含められる。

術後性のもの>発病运の時間は, 最短が術直後と記隿 されているものから術後30日目のものまでに及び，洔 間の記载されているもの10 例中 7 例 (70\%) が6日目选 に発病して㧍り，これまでの平均 $3 \sim 6$ 日目㵊発病 し易いといらことつほぐ一致する。

しかし以上のような結果とは別に我々の集計した症例

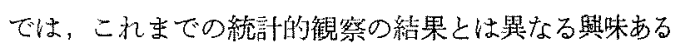
2，3の事項が諗められたので，以下これらの点を項目別 にあげて検討教察してみる。

(1) 死亡率について

1）寺山氏によれば抗生物質の使朋が発達したのは昭 和 24 年以降であつて，昭和 23 年以前はまだ発達してい なかかたことから，死亡摔娭討のために抗生物啠発達以 访の時期と抗生物質発達以淩の時期に分けているか゚, 我々は更に抗牛物質発澾以後の洔期を報告者の刲山氏の

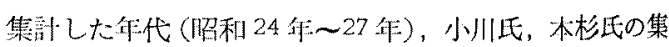
計した年代（昭和 28 年〜30 年)，我名の集計した年代(略 和 31 年〜36 年)によつて3期に分け，これらを夫々抗生 物質発達以後の時期の I 期, II 期, II 期として，各期の死 亡率を裴にま上わて及た（表 1)。この裴から抗尘物貿発

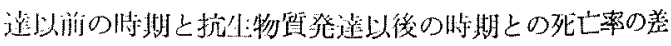
は明らかであるが，更に抗生物質発迠以後の時期に狲い ても I 期，【期， III期の各時期間の差は明䐲であり，各 牌期の推移に従つて死亡率の娍少していることが分る。

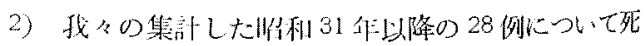

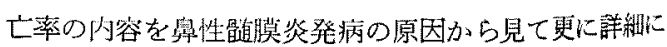


表 1 死亡菜

\begin{tabular}{|c|c|c|c|c|}
\hline 抗生物䓄発遵以前 & \multicolumn{3}{|c|}{ 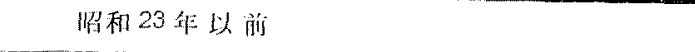 } & $91.4 \%$ \\
\hline \multirow{3}{*}{ 抗生物筫発遠以後 } & 1 期 & 昭和 24 年 27 年 & $40 \%$ (14例中 6 例) & \multirow{3}{*}{$18.7 \%$} \\
\hline & 自期 & 昭和28年〜30年 & $\begin{array}{cl}\text { (小川同) } 18.1 \% \text { (11例妕 } 2 \text { 例) } \\
\text { (本忖氏) } 13.6 \% \text { (22例巾 } 3 \text { 例) } \\
\text { 平均 } 15.2 \%\end{array}$ & \\
\hline & 面期 & 绍暞31脌〜36年 & $10.7 \%$ (28例中 3 侧) & \\
\hline
\end{tabular}

表 231 年以隆の死亡㴖の内容

\begin{tabular}{|c|c|c|c|}
\hline & 疾例数 & 死亡数 & 死亡率 \\
\hline 1. 自 然 惑 染 例 & 6 & 2 & 33.3 \\
\hline 2. 街 後 性 例 & 19 & 0 & 0 \\
\hline $\begin{array}{l}\text { 3. 上顎癌術後の放射線障 } \\
\text { 害による6の }\end{array}$ & 3 & 1 & 33.3 \\
\hline
\end{tabular}

検討してみた，即ち原因別に 1. 所謂自然感染のもの， 2.主として慢性副學腔资根本手術後に発病した術後性 のもの，3，上顎癌手術俊レントゲン照射により骨の障 害が起り，そのために䯣膜炎を起した特殊な症例，とに 分けられ，この分類に上ると表 2 の加く死亡例数は 1 に 2例，3K1例で，2の術後性のbのには○である。寺 山氏の昭和 28 年の統計でも，本杉氏の炤和31 年迄の統 計でも，自然感染例の死亡率と 2 の術後性症例の死亡率 との間には有意の差が見られないと述べているのに対 し，我タの統計ではこの雨者に有意の差が明確に認めら れ (Fisher の直接確染計算法で伦除率 $5 \%$ )，こ」にも 近年の鼻性揈膜炎の新しい面がうから゙われると思う。

そこで有意の差を生じさせた原因について考劣られる 点支文献上から要約して舟者心ついて対比してみる. 即 b

\section{自然感染例では}

1. 䣯膜炎の症状が発現してもそれまでにあるいはそ れ以後も適確な治蹽を受ける迄の時間が長い。

2. 従つて治療を開始した時は眼に画篤な状㷫に陌つ ているとが多い

3. 血行性，リンパ行性に起つたものが多く，徒つて

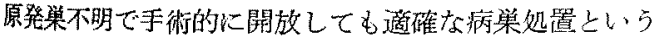
点で不充分な場合㚙ある。

4. 睬澧瘍など重篤な合併症の加わつたものが多い。

5. 抗生物質，サルフフ剂の耐性菌による死亡゙が 1 例 5

これに対して術後性例では， $|1-3|$
1. 髄膜炎症状の発兒に刘して登見が早く，优つて適 確な治療の開始が早い。

2. 損傷部は活とんど箁骨洞天盖でするが，この部の

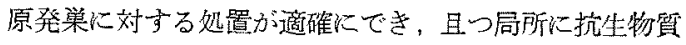
の投与が充分に行光る。

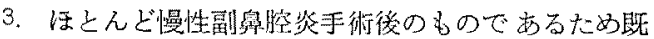
に術前，術後に抗生物質の没与が行われていたり，去の

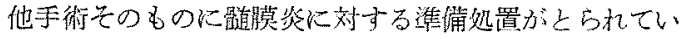
る。

4.副舅腔は既に克分䗗爬された後であるため分泌物 の旗溜は少なく，近行性やリンパ行性に起ることは少な w.

以上である。

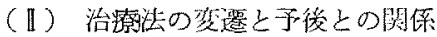

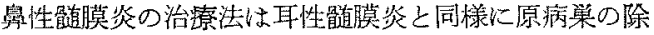
去，䯣液の排除，桬物蹽法の3者によつて行われるので あるが，從来一般には原病梁の除去なる手術的療法と咀 液排除が主とされ，浆物療法はあくまで屯附㳡的なるの にすぎなかつた。このような治療の形式は軻液の大量排 除についての幾つかの方法が考案改良されても, あるい

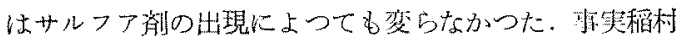
氏が統計的観案を報告した昭和 14 年を境にして，䀡和 14 年以前の死亡率とそれ以後昭和 23 年迄の死亡率とを

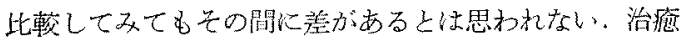
の報告が增加し死亡率心变化が生したのは䋐後になつて からで、これは抗生物筫の出現によることは明らかであ

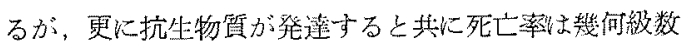

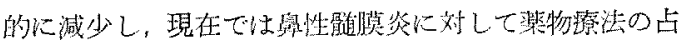

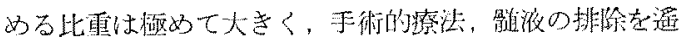

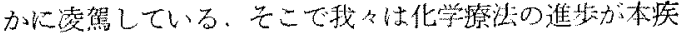
患の予後を我躍的に改善世しめている事奏と共に他の治 療法によ゙のよらな变革をもたらしつ」あるかまた現段

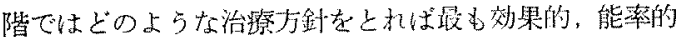

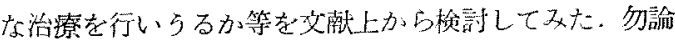
文献に現われた一面をとらえたのみであるので片手落の 


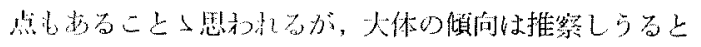
桨次名。

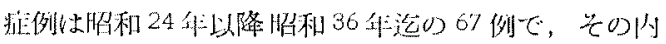
訳は先以述べた抗生物留発達以後のI期，【期，但期 の分類に犹、，I期は14例（中死亡6例)，】期は25例 (中死亡5 例)，林期は28 例(中死亡3例)である. II 期の 壮例快小氏之本杉氏との集計を整理したものである。

1）先ず治療楽凧がどのよらに変り，それに伴つて治 癒率がどのよらに変つてきているかを見る。

I 期. この時期に使用されている抗生物質を報告例か らあげると，昭和 27 年の報告例 2 例中 1 例がオーレオ マインンの内服，1例がクロラムフェーコール，テラマ イシンの内服を行つている以外他の全例 12 例恃 PC の みでこれにサルフア風が併用されている，前記の2 例は

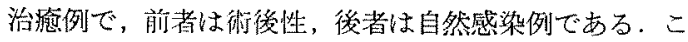
の期に相当する報告者寺山は治察について詩細に記載の ある9例について検討し，治癐した7例では1例が PC

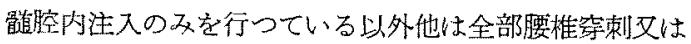

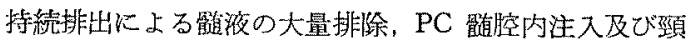
動脈注射の 3 老を併用し，死亡した2例の中 1 例は合併 症で死亡しているが，PC 髄窑内注入はやらず他の2 法の及施行し，1 例は䯣腔内注入のみを行い，他の2 法 を行つておらず，少数例のため断定はできないが，これ をもつてしても上述の3者の併用が必要であることを強 調している。この時期は抗生物質が出まわり始めた当初 で，生産数量や経济面でる十分な使用が困㩲であつたこ

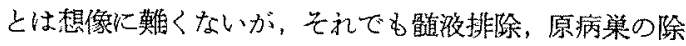
去という点でもある程度好影響が見られ，既に本知患に 対する抗生物質治療の媈かしい将来が予想される.

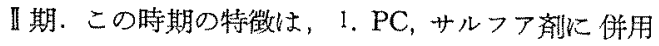
してテトラサイクリン禾物質，エリスロマイシン禿物 質，クロラムフェーコール等が使用され始め，これらの

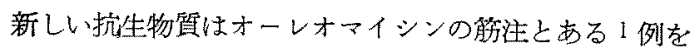
除意全例内服である。2. PC の動脈注射を施行したも のは1例もないが，I期に比して PC の使用量增加が著 しい，3.同時に PC，サルフア斉に対する耐性菌が現 わ就め，これによる死亡例末で報告されるよらになつ た.今 1 期，\|期の術後性のもので治㾤した症例中，治 療について詳悢に記荿されている。例について，链膜炎

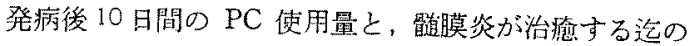
PC 総使用量とを比較すると表 $4 \mathrm{~A}$ 欄の如く、\|期の各 症例はI期に比し概してかなり多量が使用されている. この時期は PC を積極的に，大量に使用し，更に新し

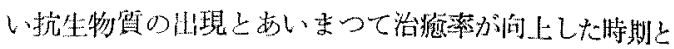

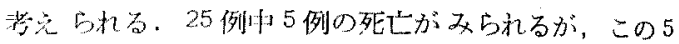

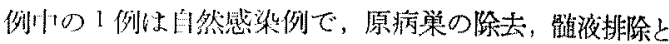
其にストマイ $3 \mathrm{~g}$ の注射をした以外， $\mathrm{PC}$ 、サルフア剂だ けを使用し，去れらの耐性菌のために死亡したるのであ り，他の4例はいずれ女畄膿瘍の合併症を伴つている。

III 期.この時期の特徽は， 1. PC，サルフフ剂に対す る涌性菌株の出現率が梄めて高くなりこれらの使用洒 偡が少なくなつた，2．テトラサイクリン緆質，エリ スロマイシン系物質，クロラムフェニコール等の抗生物 質を主に使用するようになつた。午の使用法は内服次い で施注の順に多いが，最近はこれらの抗生物貿の静脈内 注射当可能となり，去の速效性のためかなりの影度に使 用されていると推察される，代表的な婝例として，自然 感染例で方るが原病策の除去, 䯙液排除と共にアクロマ イシン $10 \mathrm{~g}$ の队服投与に上り治癒させ，PC は全く使 用してない例るある。死亡例は3例で，1例は上顎癌手 街徭骨の放射線㜔糞が原因となつて死亡したもの，1例

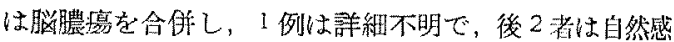
染例である。

II 期， III 期を通じ死亡例を检討すると，8例中 5 例が 脳脤瀑を併発し死亡して括り，その中の2例は治療につ いての詳縕な梖請がないので判然としないのであるが. いずれにしてもこの時期の死亡は治裺に抵抗する高度の 病変の併発に原因するものが多いことがらかがわれる。

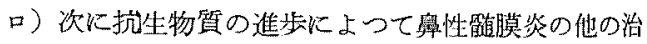
蟟法がどのよらに変化したがを検討した。

しかしこっでは従来医師にとつても患者にとつても大 きな負担であつた䯣液排除の必要性がどのように变つて いるかについてのみ迅ぐる，先さのI期，II期にあげた 術後性のもので治癔した症例中治療について詳細に諭じ た報告例之して，I期 3 例，II 期 3 例，III期 5 例の計 11 例について，1，䯣液排除のための腰椎穿刺回数，2, 排

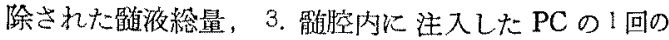

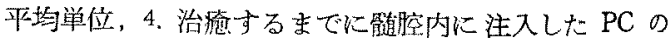
総戦位，等について检討し，その結果を表4のB 闌に まとめた，I期，机期，には比較参考のために自然感染 例を1例つっ」あげてある。これから孝察すると，

1. 穿刺回数は䐣次娍少していく傾问を見る。即ら， III 期ではI期，I期之同じよ5に回数の多い症例と，極

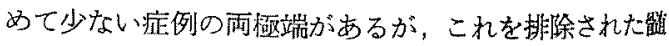
液の総量から見ると，呀刺回数は多くても排除された喟 液の祾量は1期，【期の1/2以下であり，穿刺回数の少 ないものでは比較になら双少量である。 
表 $\quad 3$

\begin{tabular}{|c|c|c|c|c|c|c|c|c|}
\hline & 報告者 & $\left|\begin{array}{|c|c|}\text { 年 } \\
\text { 令 } \\
\text { 牲 }\end{array}\right|$ & 原発柴及び経路 & 後 & $\mid$ & 病激菌 & 合拰症 & 主なる治撩法 \\
\hline 瑟 & 美山 & $\begin{array}{l}21 \\
\hat{0}\end{array}$ & $\begin{array}{l}\text { 前穊骨洞天㥺の先天的 } \\
\text { 县欠摃 }\end{array}$ & $8 \stackrel{+}{+}$ & 治 & & & 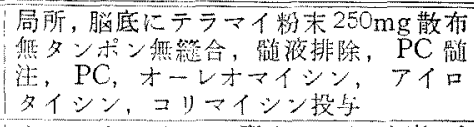 \\
\hline$\aleph^{2}$ & 岡 本 & $\begin{array}{l}20 \\
0 \\
\end{array}$ & 笘骨洞上暨 & + & $\left|x_{i}\right|$ & & & 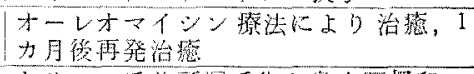 \\
\hline 0 & 间 田 & $\left|\begin{array}{c}20 \\
0\end{array}\right|$ & 特発性琕中隔膿璌 & & + 治 & & & 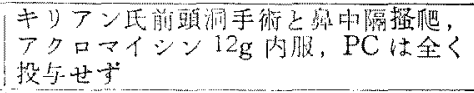 \\
\hline$x^{3}$ & 努替 & $\begin{array}{l}27 \\
0\end{array}$ & 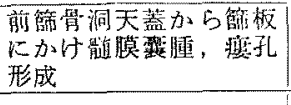 & + & 治 & & & 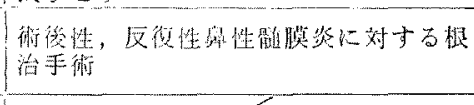 \\
\hline & 㦀格3 & $\begin{array}{ll}16 \\
9\end{array}$ & 前頭洞炎より & & + 死 & & 船泼厒 & \\
\hline
\end{tabular}

\begin{tabular}{|c|c|c|c|c|c|}
\hline \begin{tabular}{l|l}
6 & 檜 \\
33
\end{tabular} & 前頭洞炎上り & + & $\mid$ 治 & & 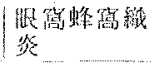 \\
\hline 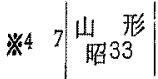 & 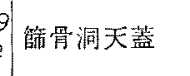 & $30 \begin{array}{c}+ \\
\text { 日 }\end{array}$ & 治 & $\begin{array}{l}\text { 奣炎观球 } \\
\text { 菌 }\end{array}$ & \\
\hline \begin{tabular}{ll|l|l|} 
& 8 & 能 \\
昭 33
\end{tabular} & 5) 籍骨洞 & 6 㔬目 & |治 & & \\
\hline
\end{tabular}

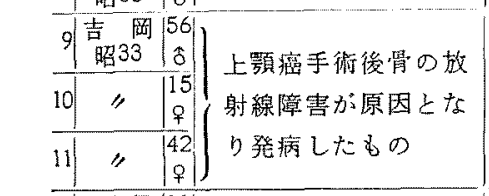

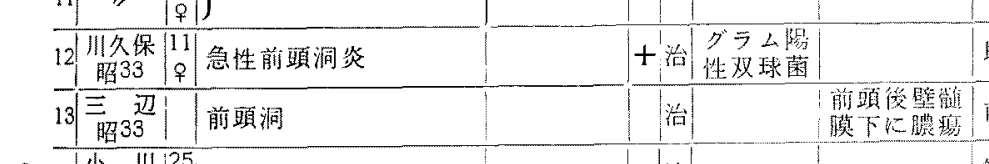

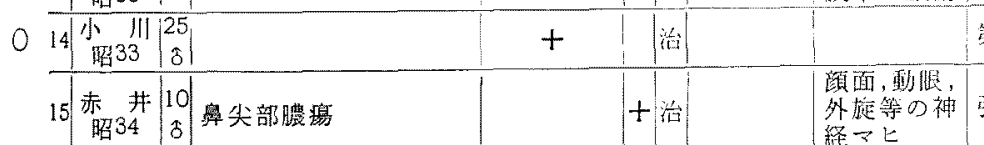

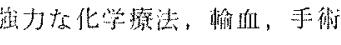

$\mathrm{PC}$ オーレオーイシン、レオシリン, サルフア剂, 術後性反復性鼠性路膜炎 に刘与る根治手衔

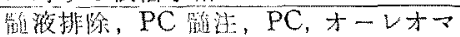
イシン、アイロタイシン内服投与

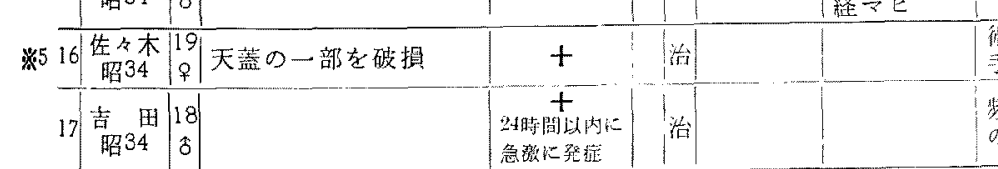

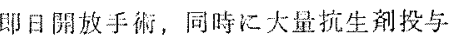

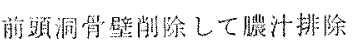

筝 4 坮幾嫼

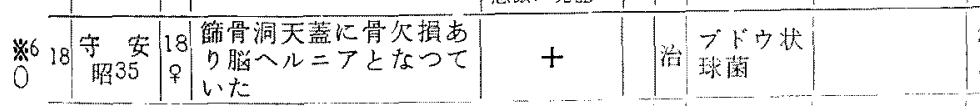

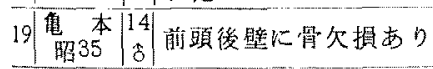

$20 \mid$ 益 1 田 $\left|\begin{array}{l}16 \\ 8\end{array}\right|$ 眼简上り(?)

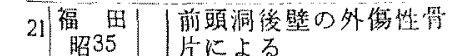

*2. 22 泉

《8 23 松

24 謂 $28 \mid$ 覆中隔矮正手術後, 泉]+

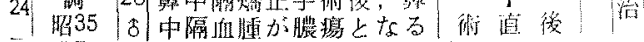

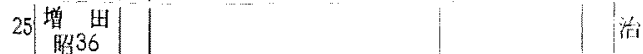

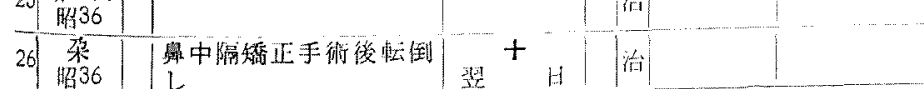

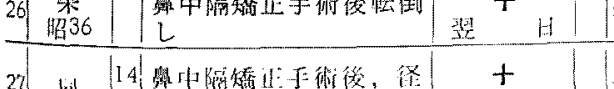

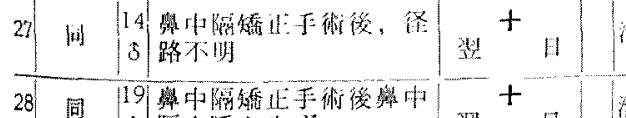

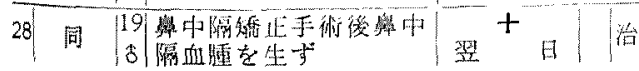

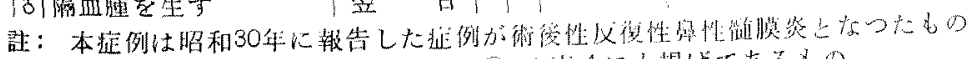

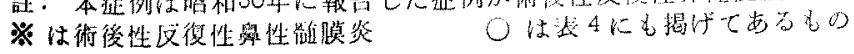

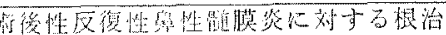
手郝

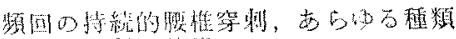

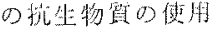

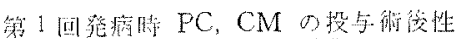

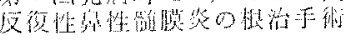

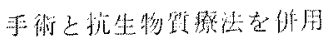

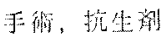

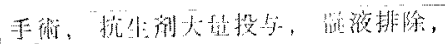

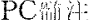

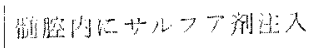

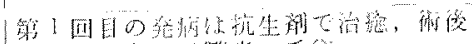

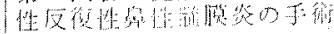

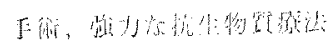

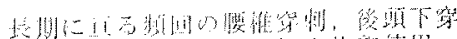

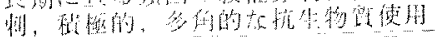

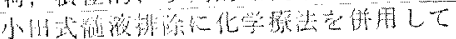
five

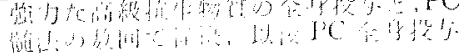

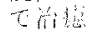

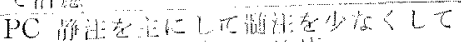

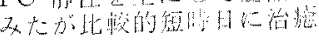


表 4

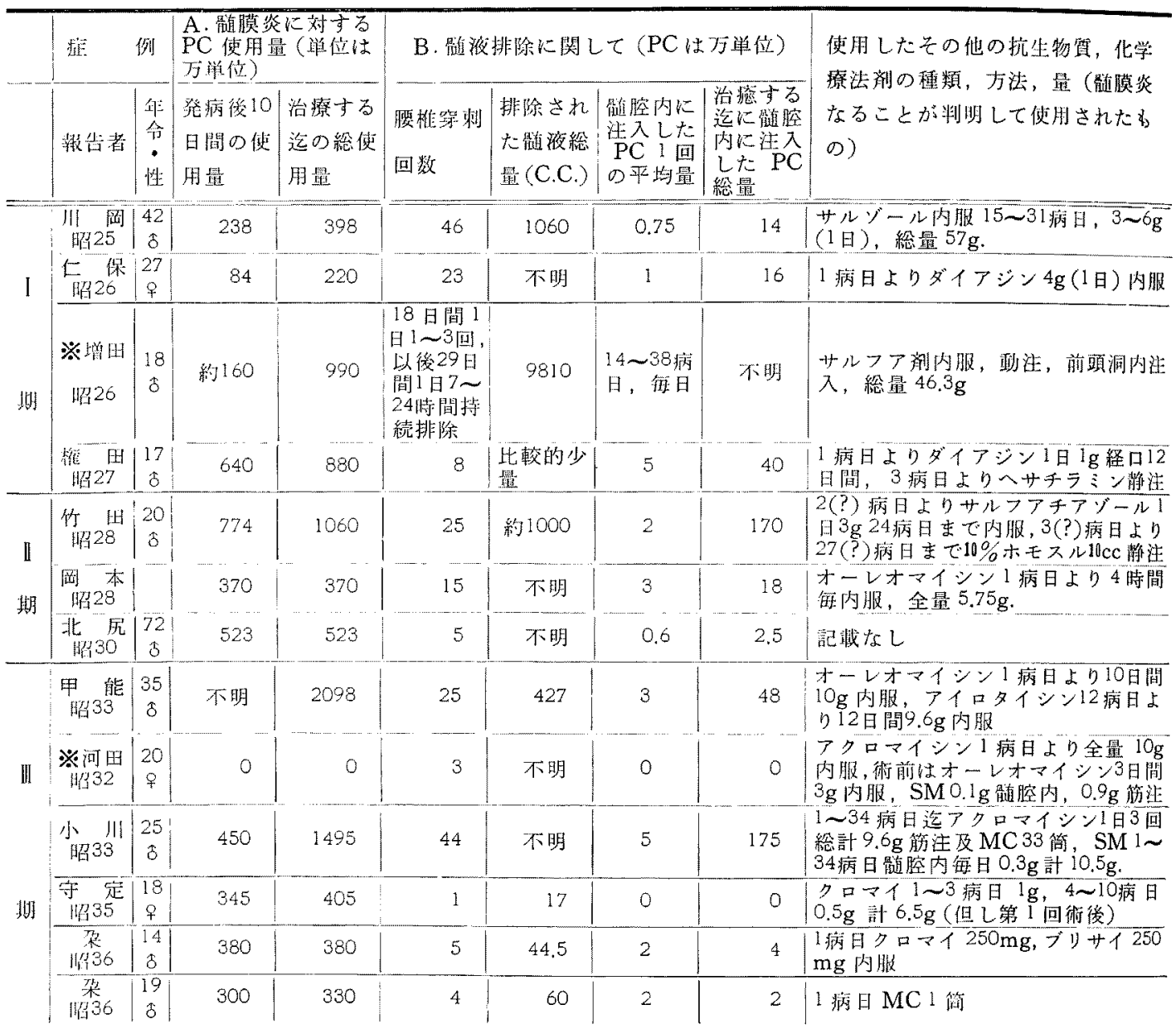

※は自然感染例であるが参考のためにあ忋た。

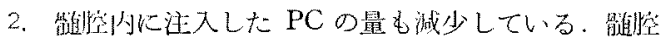

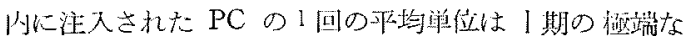

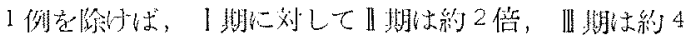

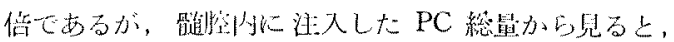

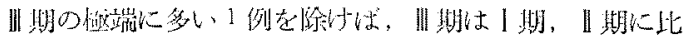

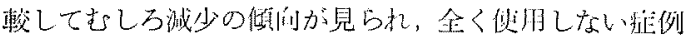
をも見る。

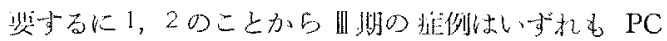

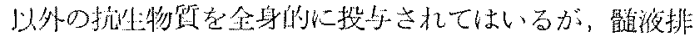
除の必要性が抗生物質の適確な侹朋によつて次筙に減少 しつょあり，治療が簡略化されていることがうが゙われ るのである。

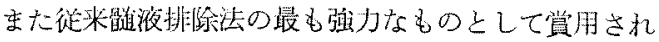

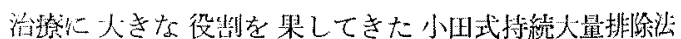

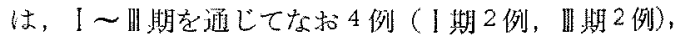

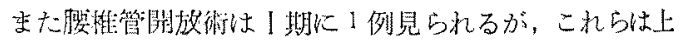

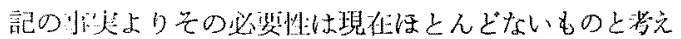
てよかるら。

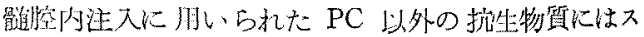
トマイ，ロイコマイシン，オーレオマイシン等の乾告が 見ら机るが，症例数も爻使用量も少なく則作用とも合せ

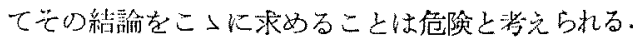

(III) 術後性反復性鼻性䯣膜炎について

我々の集計した症例のうちもう1つの大きな特徽はこ

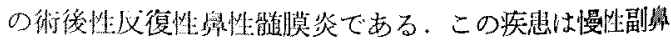

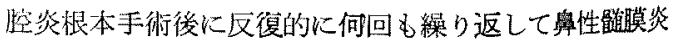




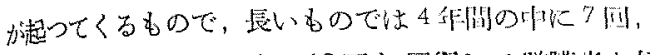

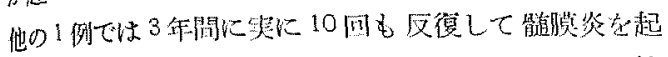

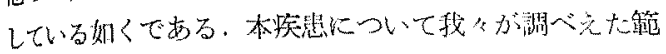

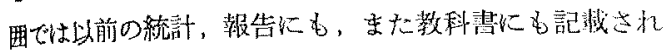
ているものはないが，死亡率の著しく高かつた時代には 当然のことであらう，我々の見た最初の報告は炤和 31 年菱山氏によるものであり，その後全部で8例を数える ことができた

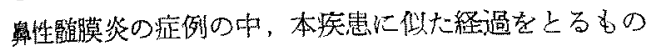

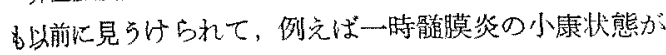

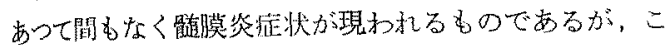
れ蛘発とは言い難い、あるいは例え再発したとして も，死亡せるるのは一応本症にはとり上け゚なかつた。

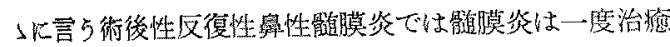
して少なくとる傅康状態化近い一時期があり，ある期間

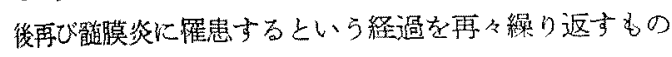
である。

我々你この8症例について文献上から統計的観察を試

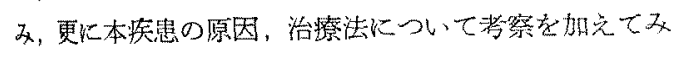
k.

反复する䯣膜炎に対して手術的に創を開放して病单部

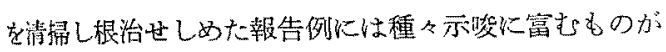
多いことから、今夫々の症例を比較检討するために， 反 反 復性鼻性骴莫炎に刘して根治手術を施行した症例之，2． 根治手街はせず姑息的に治瘾観察を行つている症例， なる2群䎲分けて，1の庭例では手衔所見に重点をお。 いずれる簡製に要点のみを記載するにとら゙めて以下に各 症列をあげてみた，症例の番号性第2 表の番号である。

1) 術後性反復性學性䯕膜炎に対して根治手術を施 行したもの

症例 4. 奥内篩骨洞手術の際, 前頭洞節骨洞天蓋上り

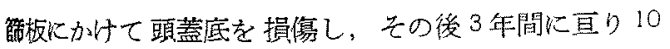
回の销膜炎症状を反復し、手術所見ではその頭蓋底骨欠

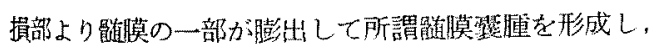

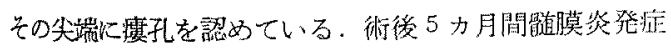
を見ない。

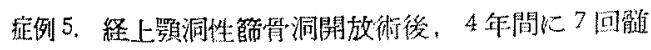

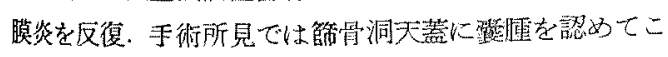
れを発生原因部位としている。術㣪髄膜焱発生は阴止さ れている。

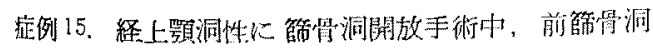
天蓋の一部を破損し以後 4 年間に7回の䯣膜炎を発怔. 手術所見では既に骨性閉鑽した前節骨洞欠撌部に一致し

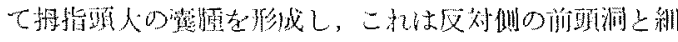

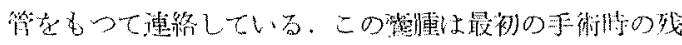

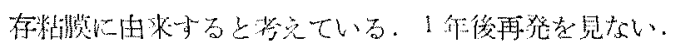

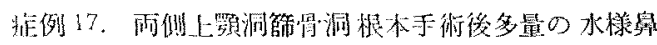

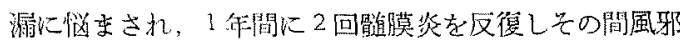
に䍜患し易く風邪を引くと高熱激烈な頭痛を俘なら。手

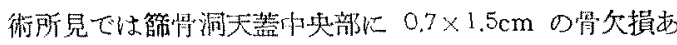
りこさより硬脳膜には蕧われていない脳が膨出し，露出

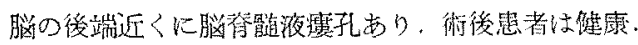

症例 21 雨側上彯洞根本手術後，再三術後性具性顝

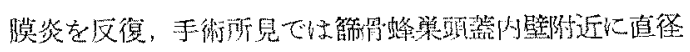

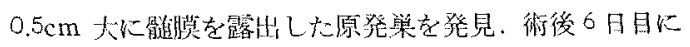

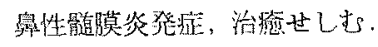

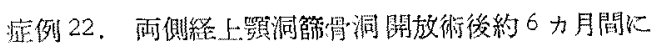

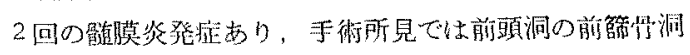
部に移行する部分飞小指尖大の脳への等孔部あり。

2）姑息的に治鍳観察を行つているもの

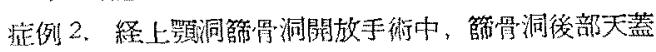

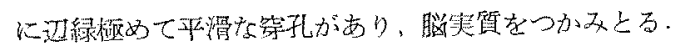

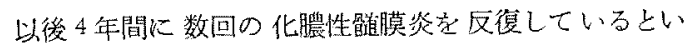
5 .

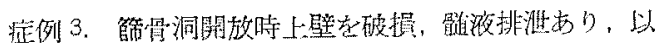
後 10 力月間に 2 回脸膜炎を起す

術後性反復性鼻性髁膜炎の症例数は昭和 31 年菱山氏 の報告を初めてとして総計8例を数え、これ蛙我々が躬

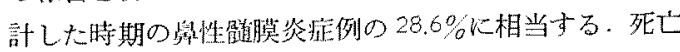

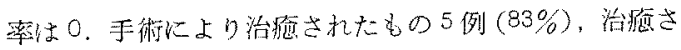
れさるもの1例 $(17 \%)$. 手術せずその都度抗生物質そ の他の適宜な治療により姑息的に治瘾过られているるの 2 例である。

根治手術を行つたものでは手術所見から，また姑息们 治尞儿上り経過観察しているものでは最初の手倠経過の 点から本疾患発生の原因部位を检柿すると，1例の前頍

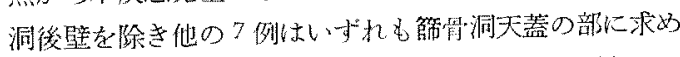

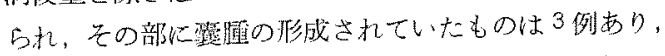

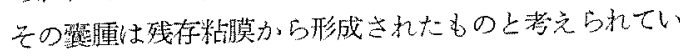
る.

手術的に処置されそのらち根治されたと考劣られる5 例中，骨欠損部に笳朕を插入して該部を塞いだものは2 例ある。手術はいずれも䯣膜炎治瘾期行われており， 筋膜の挿入は一次的㕛は二次的飞行われている.

手術施行例の報告者はいられも本朕患は手術的に処星 さ机るべきことの重要性老強調し，抗生物質比侤存少万 
ことをいましている。

抗生物質，化学瘵法の淮挤は先に述べたよらに術啳性

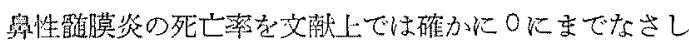

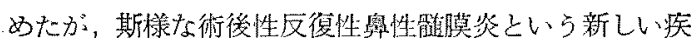

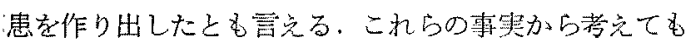
副鼻赾手術に際して篩骨洞天盖の提楊，睬膜の露出，䯣

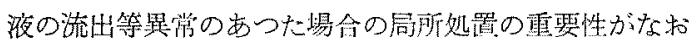
依然として存在することがよくわかるのである。

\section{結 語}

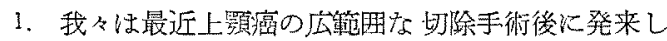

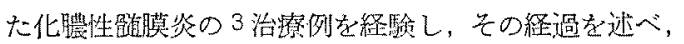

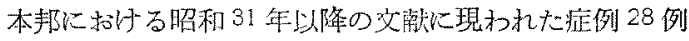

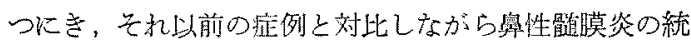
計的钼察を行つた。.

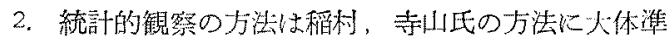

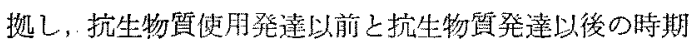
に分け，西に後者を【期，II期，四期に分け，我々の集

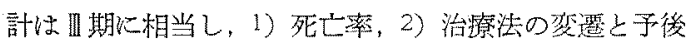

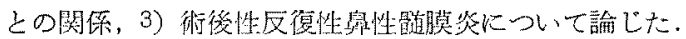

3. 死亡索では，1) 抗生物質発達以前 $91.4 \%$, 抗生物 質発灌以後 $18.7 \%$ ，I期 40\%，II 期 $15.2 \%$ ，四期 10.7

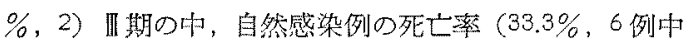
2 例死亡) $亡$ ，術後住例の死亡率 $(0 \%, 16$ 例中0) と0

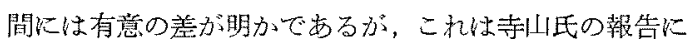
よる1期では雨若の間に有意の差がなからたことから， この差を生しるよらになつた原因について考察した，3） 文献上では術後性の死亡率がのになつた。

4. 抗生物質の発谨が本疾慗の予徭にどのよ5に影響 を及ぼしてきたかを昭和 24 年以降昭和 36 年迄の症例

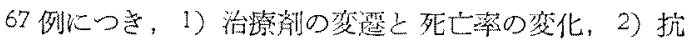
生物質の発造に上る治療法の变化特に骾液排除について 検討し，1）では】期は PC の使用方法によつて， 11 期 は PC の大且痖法及び新しい抗生物質の出現によつて,

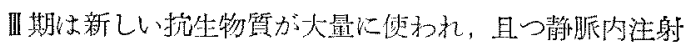

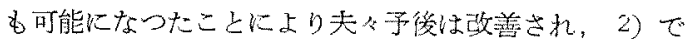

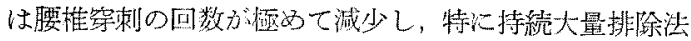
の必要性惊はとんどない上諭じた。

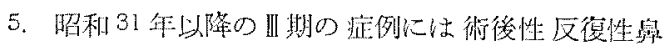
性喵膜资なる症例が初好て見的，8例 $(28.6 \%)$ 火及

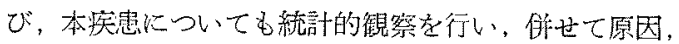

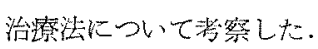

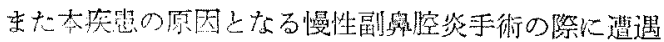

した篩骨洞天蓋の損偒，硬膜の露出，檤液の流出に際し ての処犆の必要性について論じた。

\section{文献}

1) 稻村：東北医誌，25，1，昭 14

2) 鳥居: 耳 顺，21，10，昭24. 3) 川阙：耳㬋，22,11, 炤 25 。

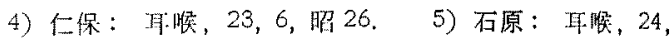

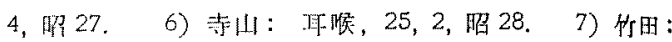

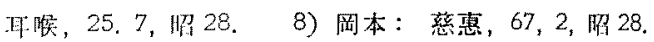

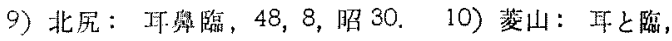
2, 1, 炤 30, 11) 蔆山：日开, 59, 10, 昭 31 , 12)

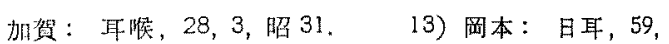

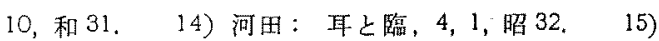
切芙: 日耳, 60,11 , 昭 32,16 ) 隆杉：日耳，61,

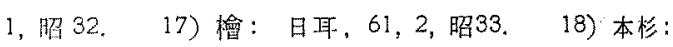

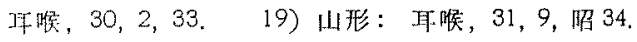
20）柙能：耳喉，31，12，昭34、21）吉岡：日耳, $61 ， 6$, 昭 33.22$)$ 川久保: 日耳, 61,9 , 昭 33 。 23) 三辺：日耳，61，9，昭 33. 24）小川：耳之謳， 5,1 , 昭 33. 25) 标井：日耳，62，5，昭 34。26) 位々朴：日耳，62、8, 昭 34.27 ) 吉田：日耳，62， 7, 昭 34.28) 守安：耳㬋，32，6，昭 35,29 ) 白

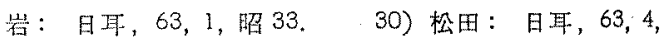
昭 35.31 ) 龟本: 日开, 63,4 , 炤 35 . 32) 益田: 日耳, 63,6 , 炤 35.33 ) 福由: 日耳, 63,10 , 昭 35 。 34) 調: 日耳, 63,11 , 昭 35, 35) 增田: 日耳, 64,

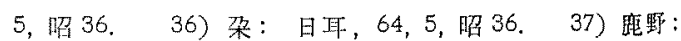

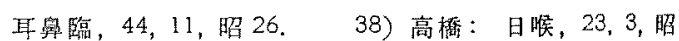
26. 39) 高橋: 日耳, 55,3 , 昭 27 . 40) 高橋: 日耳，59，10，昭 $31 ４ 41$ ) 药地：日耳, 62,8 , 昭 32 . 42) 藤森：日旦，64，7，昭 36.43) 日耳全琶：2 巻, 6 冊. 44) 後藤敏郎: 耳樏咽喉科学上巻, 昭 35.45) 内村：小児科診療，20，11，昭 32, 46)

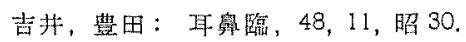

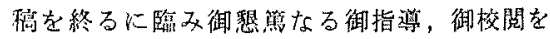
睗わつた恩師鈴木箩郎教授に深謝すると共に，

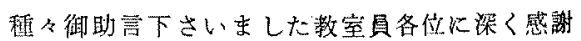
致します

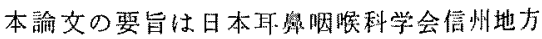
会第 35 回例会において発表した。

（原㛀到着=昭和 37.7 .3 日） 